\title{
UJI AKTIVITAS AMARA DARI PRODUK JST TERNAK, PREBIOTIK TERNAK, DAN ASAM AMINO TERNAK TERHADAP TIKUS PUTIH JANTAN (Rattus norvegicus L.) GALUR WISTAR
}

\author{
Marsella E. Sumerah ${ }^{1)}$, Adithya Yudistira ${ }^{1)}$, Karlah L.R Mansauda ${ }^{1)}$ \\ ${ }^{1)}$ Program Studi Farmasi FMIPA UNSRAT Manado, 95115
}

\begin{abstract}
Livestock JST Products, Livestock Prebiotic Products, and Livestock Amino Acid Products, are herbal products that have the potential to be used as animal feed which functions to increase appetite in livestock. This study aims to determine the amara activity of male white rats (Rattus norvegicus L.) Wistar strain. The rats were treated with an idealized treatment for Animal JST Products, Animal Prebiotic Products, and Animal Amino Acid Products, as much as $2 \mathrm{ml}$, every afternoon for 10 days using an oral sonde device and a $5 \mathrm{cc}$ dispo and the treatment group without giving the product as a negative control, which was only given food cattle in the form of concentrate. The results showed that the administration of Animal JST Products, Animal Prebiotic Products, and Animal Amino Acid Products, affected the appetite of Male White Rats (Rattus norvegicus L.) Wistar strain, which was marked by weight gain.
\end{abstract}

Keywords : $\quad$ Animal JST Products, Animal Prebiotic Products, Animal Amino Acid Products, Rattus norvegicus $L$.

\begin{abstract}
ABSTRAK
Produk JST Ternak, Produk Prebiotik Ternak, dan Produk Asam Amino Ternak, merupakan suatu produk herbal yang berpotensi untuk dimanfaatkan sebagai pakan ternak yang berfungsi dapat meningkatkan nafsu makan pada ternak. Penelitian ini bertujuan untuk mengetahui aktivitas amara terhadap Tikus Putih Jantan (Rattus norvegicus L.) Galur Wistar. Tikus diberi perlakuan dioralkan Produk JST Ternak, Produk Prebiotik Ternak, dan Produk Asam Amino Ternak, sebanyak 2 ml, setiap sore selama 10 hari dengan menggunakan alat sonde oral dan dispo $5 \mathrm{cc}$ dan kelompok perlakuan tanpa pemberian produk sebagai kontrol negatif, yang hanya diberikan pakan ternak berupa konsentrat. Hasil menunjukkan bahwa pemberian Produk JST Ternak, Produk Prebiotik Ternak, dan Produk Asam Amino Ternak, berpengaruh terhadap nafsu makan Tikus Putih Jantan (Rattus norvegicus L.) Galur Wistar, yang ditandai dengan kenaikan berat badan.
\end{abstract}

Kata Kunci : Produk JST Ternak, Produk Prebiotik Ternak, Produk Asam Amino Ternak, Rattus norvegicus $L$. 


\section{PENDAHULUAN}

Konsumsi protein hewani masyarakat Indonesia semakin hari semakin meningkat. Kualitas hewan ternak sangat ditentukan oleh pakan ternak yang merupakan salah satu indikator yang berpengaruh terhadap pertumbuhan, daya tahan tubuh, kesehatan serta produktivitas hewan ternak (Widodo, 2006). Bahan pakan yang diberikan harus mengandung asam amino yang lengkap serta berimbang sehingga penggunaan protein lebih efisien. Protein yang dikonsumsi akan disintesis menjadi asam amino dan digunakan untuk pembentukan daging sehingga bobot badan akan bertambah. Pertambahan bobot badan sangat erat hubungannya dengan asupan protein ke dalam tubuh ternak. Asupan protein dipengaruhi oleh konsumsi protein dan kecernaan protein, semakin tinggi konsumsi protein dan kecernaan protein maka asupan protein dalam tubuh ternak semakin tinggi, namun tingginya konsumsi protein akan menyebabkan rendahnya rasio efisiensi penggunaan protein. Rasio efisiensi protein akan menunjukkan tingkat koefisien seekor ternak untuk mengubah setiap gram protein yang dikonsumsi menjadi pertambahan bobot badan serta dapat menambah nafsu makan (Situmorang et al., 2013). Nafsu makan merupakan keadaan yang mendorong setiap makhluk hidup untuk memuaskan keinginannya untuk makan, selain rasa lapar.

Gangguan nafsu makan sendiri merupakan gangguan klinis yang penting namun sering kali diabaikan. Nafsu makan berkurang ketika keinginan untuk makan tidak sebanyak kondisi sebelumnya, atau disebabkan oleh suatu penyakit atau kelainan tertentu. Berkurangnya nafsu makan diyakini sebagai faktor utama terjadinya kurang gizi dan dapat berdampak pada penurunan berat badan yang tidak disengaja (Guyton, 1996 ; Hall, 2011).

Berdasarkan faktor-faktor di atas, penulis tertarik untuk melakukan penelitian tentang suatu produk pakan ternak yang dapat meningkatkan nafsu makan pada ternak. Dalam hal ini adalah Produk JST ternak, Prebiotik ternak, dan Asam Amino ternak, dimana Produk JST ternak, Prebiotik ternak, dan Asam Amino ternak merupakan suatu produk yang digunakan sebagai penambah nafsu makan pada ternak, yang menurut testimoni dari beberapa orang sangat berpengaruh, karena pada penggunaannya dapat mempercepat pengosongan lambung pada ternak, sehingga akan menambah nafsu makan (Guyton, 1996 ; Hall, 2011).

Pada penelitian ini dilakukan uji aktivitas amara dari produk JST (Jamu Sehat Tubuh) ternak, Prebiotik ternak, dan Asam Amino ternak pada Tikus Putih Jantan (Rattus norvegicus L.) Galur Wistar.

\section{METODOLOGI PENELITIAN}

\section{Waktu dan Tempat Penelitian}

Penelitian ini dilaksanakan pada bulan Oktober - Desember 2019 di Laboratorium Farmasi Lanjut Fakultas Matematika dan Imu Pengetahuan Alam Universitas Sam Ratulangi.

\section{Bentuk Penelitian}

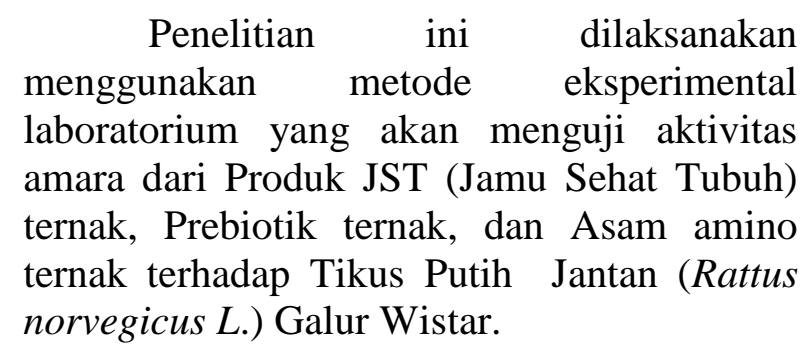

\section{Alat dan Bahan}

Alat

Alat yang digunakan dalam penelitian ini yaitu masker, sarung tangan, dispo $5 \mathrm{cc}$, sonde oral, kandang tikus, pot makanan, botol minuman, dan timbangan.

\section{Bahan}

Bahan-bahan yang digunakan yaitu Produk JST (Jamu Sehat Tubuh) ternak, Prebiotik ternak, Asam Amino ternak, aquades dan 12 ekor hewan uji yaitu Tikus Putih Jantan Galur Wistar. 


\section{Prosedur Penelitian}

\section{Pengambilan dan Persiapan Hewan Uji}

Dalam penyiapan bahan uji digunakan 12 ekor tikus putih jantan (Rattus norvegicus L.) diambil di Desa Kamanga Satu, Kecamatan Tompaso, Kabupaten Minahasa, dengan berat badan yang bervariasi yaitu 120 - 200 gram. Hewan uji selanjutnya disimpan di laboratorium Farmasi Lanjut Fakultas Matematika dan Ilmu Pengetahuan Alam selama 1 minggu.

\section{Pengelompokan Hewan Uji}

Hewan uji sebanyak 12 ekor tikus putih jantan (Rattus norvegicus L.) dibagi 4 kelompok perlakuan, dimana kelompok 1 diberikan Produk Asam Amino ternak, kelompok 2 diberikan Produk Prebiotik ternak, kelompok 3 diberikan Produk JST (Jamu Sehat Tubuh) ternak, dan kelompok 4 tanpa pemberian produk.

\section{Penyiapan Kontrol Negatif}

Hewan uji yang menjadi kontrol negatif adalah hewan uji kelompok ke-4 yang hanya diberikan pakan ternak berupa konsentrat.

\section{Pemberian Produk}

Hewan uji kelompok 1 diberikan Produk Asam Amino ternak, kelompok 2 diberikan Produk Prebiotik ternak, dan kelompok yang ke-3 diberikan Produk JST (Jamu Sehat Tubuh) ternak, selanjutnya dioralkan pada masing-masing tikus putih jantan (Rattus norvegicus L.) sebanyak $2 \mathrm{ml}$, setiap sore selama 10 hari dengan menggunakan alat sonde oral dan dispo $5 \mathrm{cc}$.

\section{Penimbangan Hewan Uji}

Setiap hewan uji ditimbang dahulu sebelum diberikan perlakuan untuk mengetahui berat badan awal dari masingmasing tikus putih (Rattus norvegicus L.)
Hewan uji ditimbang setiap hari selama 10 hari setelah perlakuan. Berat badan hewan uji kemudian dicatat dan dibandingkan berat badan awal dan berat badan akhir.

\section{Analisis Data}

Data yang dihasilkan akan di interpretasikan dalam bentuk grafik.

\section{HASIL DAN PEMBAHASAN}

Hasil Penimbangan Berat Badan Tikus Putih Jantan (Rattus norvegicus L.) Galur Wistar Tanpa Pemberian Produk (Kontrol Negatif)

Penelitian ini menggunakan Tikus Putih Jantan (Rattus norvegicus L.) Galur Wistar sebagai hewan uji dan pakan konsentrat sebagai kontrol negatif. Penggunaan hewan percobaan pada penelitian kesehatan banyak dilakukan untuk uji kelayakan atau keamanan suatu bahan obat dan juga untuk penelitian yang berkaitan dengan suatu penyakit (Tolistiawaty et al, 2014). Penggunaan Tikus Putih Jantan (Rattus norvegicus L.) Galur Wistar sebagai hewan uji pada penelitian ini karena tikus putih jantan tidak berpengaruh pada siklus hormonal yang nantinya akan berpengaruh pada hasil penelitian (Nurwahyunani, 2006). Tikus putih jantan banyak digunakan dibandingkan dengan tikus betina karena tikus jantan menunjukkan periode pertumbuhan yang lebih lama dibandingkan dengan betina (Moore, 2000). Pemberian bahan uji pada hewan coba harus diupayakan sebaik mungkin agar tidak menimbulkan stress atau nyeri pada hewan. Adapun cara-cara pemberian bahan uji diantaranya : intreaperitonial, subkutan dan intramuskular, intradermal, peroral, dan intravena (Kusumawati, 2004).

Aklimatisasi hewan dilakukan selama 7 hari. Aklimatisasi merupakan suatu upaya penyesuaian fisiologis atau adaptasi dari suatu organisme terhadap suatu lingkungan baru yang akan dimasukinya. Hal ini didasarkan pada kemampuan mikroorganisme untuk 
dapat mengatur morfologi, perilaku, dan jalur metabolisme biokimia di dalam tubuhnya untuk menyesuaikannya dengan lingkungan. Tujuan aklimatisasi pada hewan percobaan ini adalah agar hewan dapat menyesuaikan diri dengan lingkungannya. (Rittner, 2005).

Kenaikan berat badan tikus putih jantan (Rattus norvegicus L.) galur wistar tanpa pemberian produk dapat dilihat pada Gambar 1.

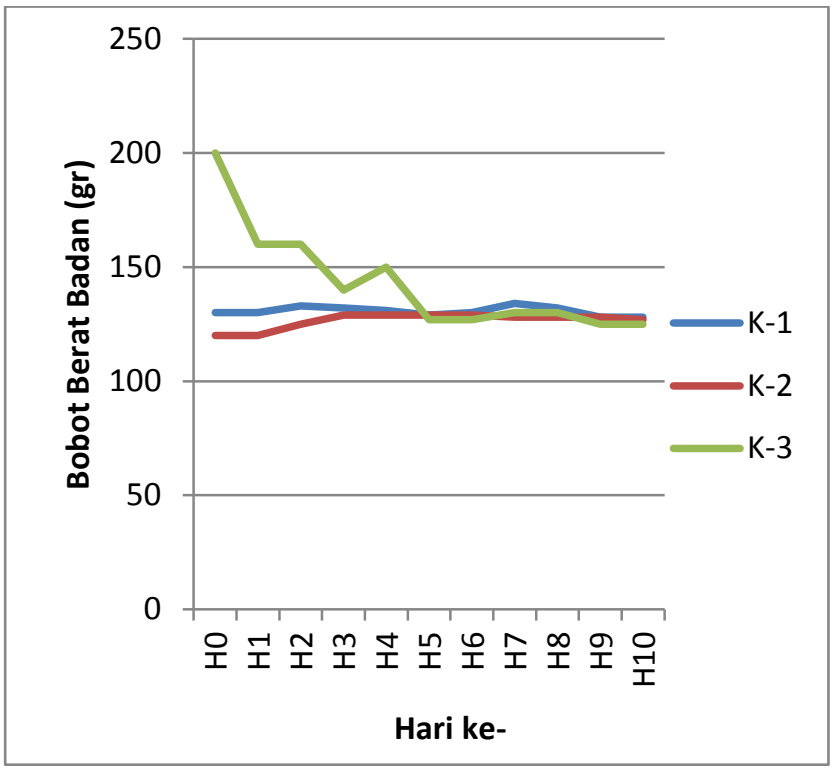

Gambar 1. Kenaikan Berat Badan Tikus Putih Jantan (Rattus norvegicus L.) Galur Wistar tanpa Pemberian Produk. (K$1,2,3=$ Kelompok perlakuan Kontrol Negatif).

Berdasarkan Gambar 1. Berat badan tikus putih jantan (Rattus norvegicus L.) galur wistar menunjukkan bahwa tanpa pemberian produk selama 10 hari perlakuan, dan hanya diberikan pakan berupa konsentrat, berat badan tikus putih jantan (Rattus norvegicus L.) galur wistar mengalami penurunan dari berat badan awal $\mathrm{K}_{-1}=130$ gram, dan dibandingkan dengan berat badan akhir turun menjadi 128 gram, $\mathrm{K}_{-2}=120$ gram, dibandingkan dengan berat badan akhir turun menjadi 127 gram, dan $\mathrm{K}_{-3}=200$ gram, dibandingkan dengan berat badan akhir turun menjadi 125 gram. Kelompok kontrol negatif yaitu kelompok tanpa pemberian produk selama 10 hari perlakuan, dan hanya diberikan pakan berupa konsentrat. Konsentrat merupakan bahan makanan dengan kadar serat kasar kurang dari 20\% dan nutrisi dapat dicerna lebih dari $80 \%$ (Cullison dan Lowrey, 2003). Secara umum konsentrat mengandung serat kasar rendah, mengandung karbohidrat, protein, lemak yang relatif lebih banyak tapi jumlahnya bervariasi dan mempunyai sifat yang mudah dicerna (Tilman et al, 2002). Selain itu palatabilitas pakan, cita rasa, tekstur, ukuran dan konsistensi pakan juga turut mempengaruhi tingkat konsumsi pakan (Wiseman dan Cole, 2002). Sifat dan komposisi pakan juga akan turut mempengaruhi tingkat konsumsi. Pakan yang berkualitas baik akan memiliki tingkat konsumsi yang relatif tinggi bila dibandingkan dengan pakan berkualitas rendah. Kualitas pakan dapat dilihat dari kandungan zat makanan. Berdasarkan National Research Council (2014), konsumsi harian rata-rata tikus putih jantan galur wistar dalam masa pertumbuhan adalah 15-20 gram, Hal ini dapat dijelaskan bila mengamati pola tingkah laku tikus putih jantan selama pemeliharaan, tikus cenderung lebih aktif, ternak yang lebih aktif dengan suhu kandang yang tinggi cenderung lebih mudah terkena stress dibanding yang kurang aktif. Tikus putih jantan lebih muudah mengalami stress sehingga konsumsinya pun turun (Smith dan Mangkoewidjojo 1988). Ini terlihat dari nilai konsumsi rata-ratanya yang lebih rendah dari yang semestinya.

\section{Hasil Penimbangan Berat Badan Tikus Putih Jantan (Rattus norvegicus L.) Galur Wistar dengan Pemberian Produk JST (Jamu Sehat Tubuh) Ternak}

Kenaikan berat badan tikus putih jantan (Rattus norvegicus L.) galur wistar dengan pemberian produk JST (Jamu Sehat Tubuh) Ternak dapat dilihat pada Gambar 2. 


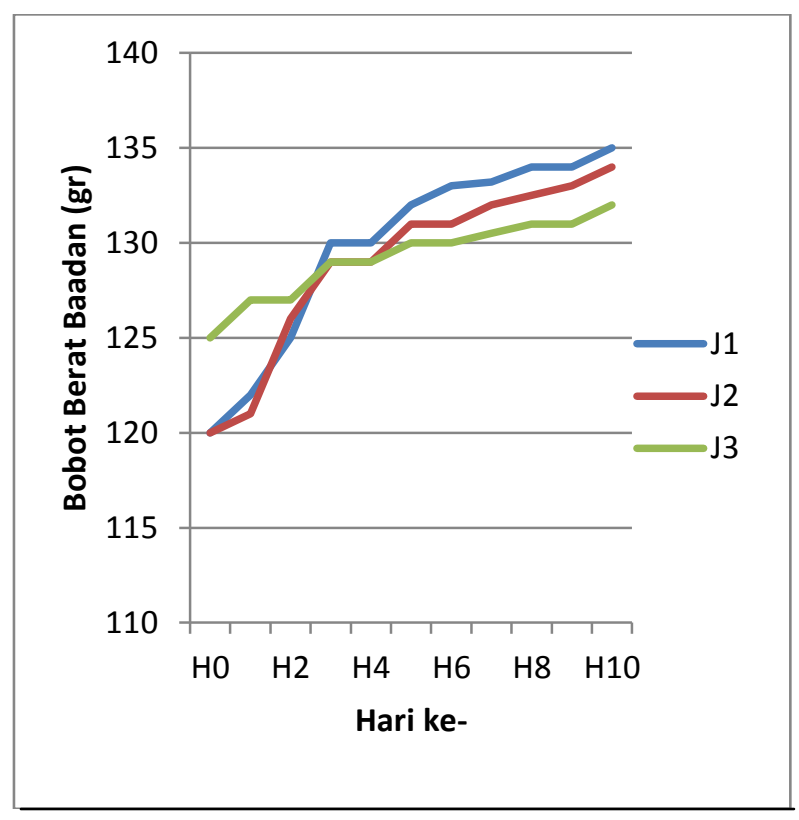

Gambar 2. Kenaikan Berat Badan Tikus Putih Jantan (Rattus norvegicus L.) Galur Wistar dengan Pemberian Produk JST Ternak. $\quad\left(\mathrm{J}_{1,2,3}=\right.$ Kelompok perlakuan Produk JST).

Berdasarkan Gambar 2. Kenaikan berat badan tikus putih menunjukkan bahwa pemberian dengan Produk JST ternak pada tikus putih jantan (Rattus norvegicus L.) galur wistar, terlihat jelas bahwa ada peningkatan berat badan setelah diberikan perlakuan selama 10 hari, berat badan awal hewan uji sekitar 120 gram naik sampai sekitar 135 gram. Produk JST merupakan suatu produk herbal. Penggunaan herbal dari jamu ternak, Menurut Dwiyanto dan Prijono (2007) menyatakan bahwa obat tradisional adalah obat yang terbuat dari bahan alami terutama tumbuhan dan merupakan warisan budaya bangsa yang telah digunakan turun temurun.

Produk JST terbuat dari campuran gula aren, tepung beras, labu, buah mengkudu, susu bubuk, lidah buaya, daun kelor, buah maja, dan air kelapa, dan lainlain. Gula aren atau gula merah, dikenal sebagai sumber energi karena kandungan karbohidrat dan gulanya serta kandungan sukrosa $66,19 \%$, gula pereduksi $5,99 \%$ dan $15,37 \%$ zat bukan gula yang larut dalam air
(Karnosuhardjo, 2009). Hasil penelitian yang dilakukan oleh Fera Aryanti et al, (2013), menunjukkan bahwa pemberian air gula merah $1 \%$ pada ayam kampung pedaging dapat meningkatkan bobot badan, konsumsi makanan, dan menurunkan tingkat mortalitas. Dari informasi yang ada, air kelapa diketahui mengandung natrium $(\mathrm{Na})$ dan kalium (K) yang dapat berperan untuk menggantikan cairan elektrolit yang hilang (Saat et al, 2002). Menurut Yong et al, (2009) hormon pertumbuhan yang terdapat pada air kelapa antara lain yaitu : auksin, sitokinin, dan giberilin, sedangkan enzim yang terdapat pada air kelapa yaitu : posfatase, katalase, diartase, peroksidase, dan RNA polymerase.

Hasil penelitian yang dilakukan oleh Susila et al, (2019), menunjukkan bahwa pemberian air kelapa $1 \%$ melalui air minum pada ayam broiler memberikan pengaruh yang nyata terhadap berat badan akhir, dan pertambahan berat badan. Menurut Wakradihardja dan Erdavit, (2003) juga menyatakan bahwa mengkudu, yang terkandung dalam jamu dapat meningkatkan nafsu makan dan meningkatkan metabolisme tubuh ternak.

\section{Hasil Pengamatan Pemberian Produk Prebiotik Ternak}

Produk lain yang digunakan dalam penelitian ini adalah Produk Prebiotik Ternak. Menurut Salminen dan Yuan (2009) prebiotik adalah nondigestible food ingredient yang memiliki pengaruh baik terhadap host (inang) dengan memicu aktifitas, pertumbuhan selektif, atau keduanya terhadap satu jenis atau lebih mikroba penghuni kolon.

Kenaikan berat badan tikus putih jantan (Rattus norvegicus L.) galur wistar dengan pemberian produk Prebiotik Ternak dapat dilihat pada Gambar 3. 


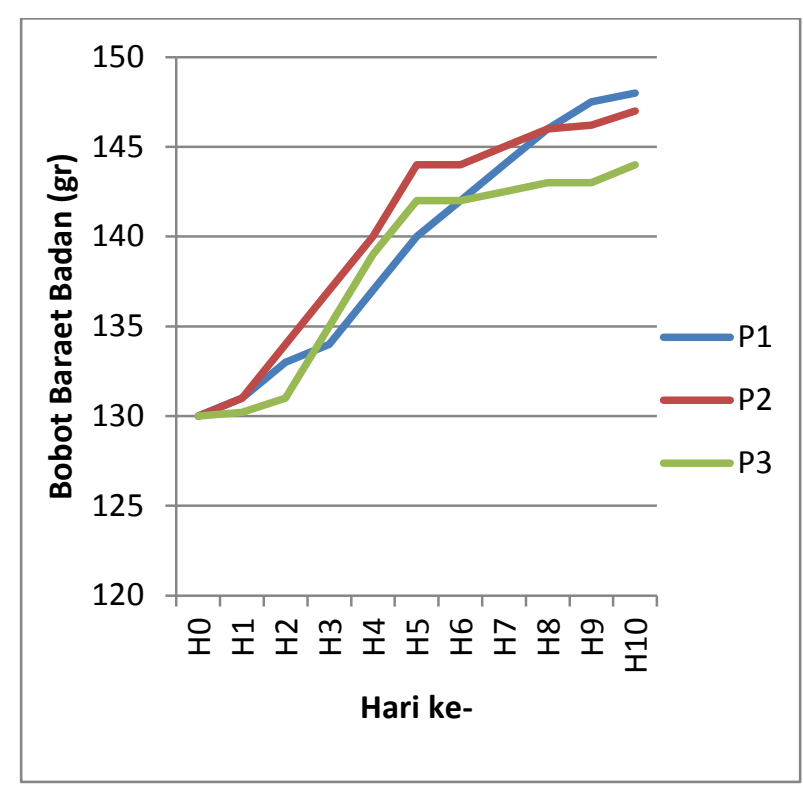

Gambar 3. Kenaikan Berat Badan Tikus Putih Jantan (Rattus norvegicus L.) Galur Wistar dengan Pemberian Produk Prebiotik Ternak. $\quad\left(\mathrm{P}_{123}=\right.$ Kelompok perlakuan Produk Prebiotik).

Berdasarkan Gambar 3. Kenaikan berat badan tikus putih jantan (Rattus norvegicus L.) galur wistar menunjukkan bahwa pemberian dengan Produk Prebiotik ternak pada tikus putih jantan (Rattus norvegicus $L$.) galur wistar, naik lebih tinggi hingga 148 gram dari 130 gram berat badan awal.

Menurut Ringgo et al. (2010) prebiotik merupakan karbohidrat yang diklasifikasikan menurut ukuran molekul atau derajat polimerisasi dan terdiri dari monosakarida, oligosakarida, dan polisakarida yang mampu memberikan asupan makanan bagi pertumbuhan bakteri. Hasil penelitian dari Merrifield et al, (2010) Prebiotik yang diberikan akan berperan dalam meningkatkan pertumbuhan, tingkat kelangsungan hidup, sistem kekebalan tubuh, efisiensi pakan, serta komposisi bakteri yang menguntungkan dalam saluran pencernaan ikan. Penelitian dari Li et al, (2008) melaporkan bahwa prebiotik berperan sebagai nutrisi terhadap probiotik sehingga dapat meningkatkan keseimbangan mikroorganisme di dalam saluran pencernaan, sementara bakteri probiotik dapat menghasilkan produk metabolisme yang bermanfaat bagi tubuh ternak.

Menurut Manning dan Gibson (2004) menyatakan bahwa prebiotik mampu menstimulasi pertumbuhan atau aktivitas metabolik bakteri menguntungkan di dalam usus dan mampu meningkatkan respons imun.

Hasil penelitian dari Widanarni et al, (2012) laju pertumbuhan tertinggi terdapat pada perlakuan prebiotik, hal ini diduga pemberian prebiotik dapat memodulasi mikrobiota dalam saluran pencernaan.

\section{Hasil Pengamatan Pemberian Produk Asam Amino Ternak}

Kenaikan berat badan tikus putih jantan (Rattus norvegicus L.) galur wistar dengan pemberian produk Asam Amino Ternak dapat dilihat pada Gambar 4.

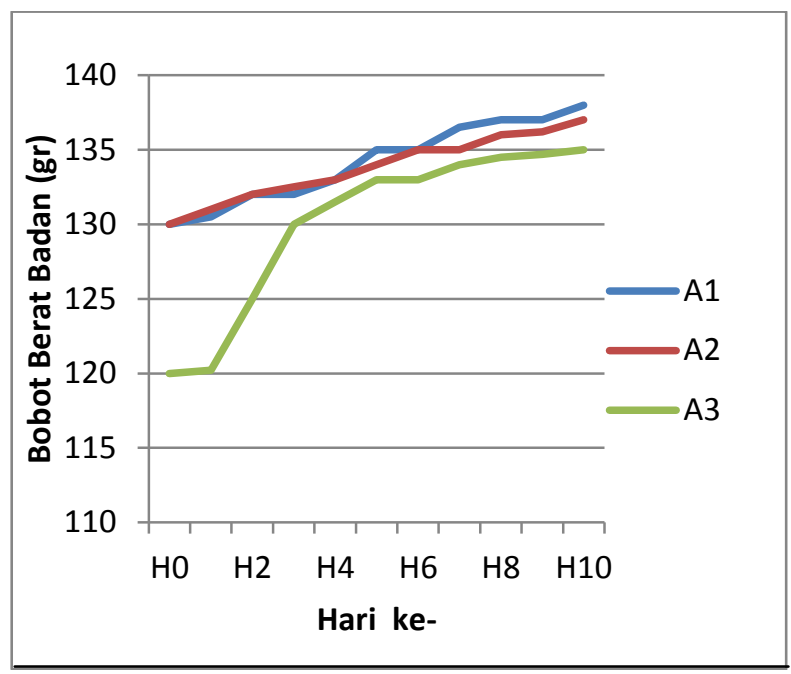

Gambar 4. Kenaikan Berat Badan Tikus Putih Jantan (Rattus norvegicus L.) Galur Wistar dengan Pemberian Produk Asam Amino Ternak $\left(\mathrm{A}_{123}=\right.$ Kelompok perlakuan Produk Asam Amino).

Berdasarkan Gambar 4. Kenaikan berat badan tikus putih jantan (Rattus norvegicus L.) galur wistar menunjukkan bahwa pemberian dengan Produk Asam 
Amino ternak pada tikus putih jantan (Rattus norvegicus $L$.) galur wistar, peningkatan berat badan dari berat badan awal 130 gram naik sampai 138 gram.

Menurut Sison (2010) Asam amino merupakan komponen dari protein yang berfungsi membentuk jaringan tubuh ternak. Konsep ideal protein didasarkan pada relatif asam amino yang dibutuhkan oleh ternak untuk pertumbuhan dan pemeliharaan, dimana kebutuhan dari asam amino tersebut akan berbeda menurut jenis kelamin, umur, berat dan juga genetik dari ternak, namun perbandingan antara asam amino esensial selalu sama. Hal ini karena protein dalam tubuh digunakan untuk pertumbuhan jaringan otot yang dicerminkan oleh pertambahan bobot badan dan pemenuhan kebutuhan hidup pokok (Kompiang et al, 2001).

Menurut Heptarina et al, (2010) membuktikan bahwa ketersediaan asam amino pakan untuk disimpan menjadi asam amino tubuh atau protein tubuh semakin besar dengan penambahan protein dalam pakan. Penggunaan pakan dengan kandungan protein yang sesuai kebutuhan dan jumlah optimum akan menyebabkan pembentukan jaringan baru sehingga laju pertumbuhan meningkat (Marzuqi et al, 2012).

Berdasarkan hasil penelitian, dari ketiga produk yang digunakan, Produk Prebiotik yang menunjukkan pertambahan bobot berat badan tertinggi, dan yang terendah adalah Produk JST. Ketiga Produk apabila dibandingkan dengan kontrol negatif, yang diberikan pakan (konsentrat), berat badan tikus putih jantan (Rattus norvegicus L.) galur wistar, kelonpok kontrol negatif tidak mengalami kenaikan berat badan.

\section{KESIMPULAN}

Berdasarkan hasil penelitian yang telah dilakukan dapat disimpulkan bahwa pada Produk JST Ternak, Produk Prebiotik Ternak, dan Produk Asam Amino Ternak, memiliki aktivitas amara (penambah nafsu makan) pada Tikus Putih Jantan (Rattus norvegicus L.) galur wistar yang ditandai dengan peningkatan berat badan.

\section{SARAN}

Perlu dilakukan penelitian lebih lanjut mengenai uji aktivitas amara Produk JST ternak, Produk Prebiotik ternak, dan Produk Asam Amino ternak, pada hewan uji lain.

\section{DAFTAR PUSTAKA}

Duncan SH, and Flint HJ. 2013. Probiotics and prebiotics and health in ageing populations. Maturitas 75 (1) : 44-50.

Faudjar SS, Mehrishi P, Bishohnoi S, Sharma A. 2016. Role of Probiotics in human health and disease: an update. International Journal of Current Microbiology and Applied Sciences 5 (6) : 328-344.

Heptarina, D. M.A. Suprayudi, I. Mokoginta dan D. Yaniharto. 2010. Pengaruh Pemberian Pakan dengan Kadar Protein Berbeda terhadap Pertumbuhan Yuwana Udang Putih (Litopenaeus vanamei). Fakultas Perikanan dan Ilmu Kelautan, IPB Bogor, hal 2.

Kompiang, I.P. dan Supriyati. 2001. Pengaruh cara pemberian pakan dan ampas sagu terfermentasi terhadap kinerja ayam pedaging, Jurnal Ilmu Ternak Vet. 6 (1) : 14-20.

Marzuqi, M., N.W. Astuti dan K. Suwirya, 2012. Pengaruh Kadar Protein dan Rasio Pemberian Pakan terhadap Pertumbuhan Ikan Kerapu Macan (Epinephelus fuscoguttatus). Jurnal Ilmu dan Teknologi Kelautan Tropis, $1(4)$ : 55-56.

Situmorang, N.A., Mahfudz, L.D., Atmomarsono, U., 2013. Pengaruh pemberian tepung rumput laut (Gracilaria verrucosa) dalam ransum terhadap efisiensi penggunaan protein ayam broiler. Jurnal Animal Agriculture. 2(2) : 49-56. 
Sugito, J. 2001. Kamus Umum Perternakan. Penebar Swadaya, Jakarta.

Tilman, A.D, Hatardi H., Reksohadiprodjo, S. Lebdosoekojo S. 2002. Ilmu Makanan Ternak Dasar. Edisi Keenam, Fakultas Peternakan UGM, Yogyakarta.

Tolistiawaty I, Widjaja J, Sumolang P, Oktaviani. 2014. Gambaran Kesehatan pada Mencit (Mus musculus) di Intalasi Hewan Coba. Jurnal Vektor Penyakit 8 (1) : 27-32.

Winarno, F.G. 2002. Kimia Pangan dan Gizi. PT Gramedia, Jakarta. 